\title{
Görsel Hikaye Anlatımı Bağlamında Basılı Reklamlarda Fotoğraf Kullanımı
}

\author{
Arş. Gör. Dr. Pelin Öztürk Göçmen
}

Makale Geliş Tarihi: 23.12.2015

Yayına Kabul Tarihi: 20.04.2016

\section{Öz}

İletişimin gerçekleşme biçiminin değişmesinde önemli rol oynayan teknoloji, aynı zamanda yepyeni bir görsel bellek oluşmasına da katkıda bulunmaktadır. Reklamlarda, görsellerin ve metinlerin bir arada kullanılarak söylemlerin iç içe geçirildiğini ve anlamın bu şekilde üretildiğini gözlemlemek mümkündür. Günümüzde fotografik imgenin ön planda, büyük boyutta yer aldığı; yazının destek amaçlı kullanıldığı reklamlara sıkça rastlanmaktadır. Gerçekliğin yeniden sunumu bağlamında fotoğrafin tanıtım mecralarında kullanımı, daha inandırıcı ve daha çok ikna edebilen reklamlar üretilmesine yardımcı olmaktadır.

Bu çalışmanın amacı, 2010 yııından bu yana Kırmızı- Basında En iyiler Reklam Ödülleri içerisinden büyük ödül olan "Kıpkırmızı" ödülü almış reklamları incelemektir. Verilerin toplanması, analizi, metin ve görsel içeriğin incelenmesinde içerik analizine dayalı nitel araştırma yöntemi kullanılmıştır. Bu reklamlarda fotoğrafin yeri ve görsel iletide bulunan metin oluşturucuları irdelenmiştir. Bu reklamlar, görsel hikâye anlatımı bağlamında ve içerik analizi yöntemi ile analiz edilmiştir.

Anahtar Kelimeler: Reklam, Fotoğraf, Kırmızı Ödülleri

\section{USE OF PHOTOGRAPHY AT PRINT ADS IN THE CONCEPT OF VISUAL STORYTELLING}

\begin{abstract}
Technology, with having significant role at the changing way of communication, is a contributor of composing new visual memories. It is possible to observe to create the meaning with using interpenetrating discourses of visual images and texts in the advertisements. Today, photographic image is being used at the forefront with huge sizes despite text that is being used for supporting the image at the advertisements. As a representation of reality, photography being used at advertisements support them for being more persuasive and convincing.

The purpose of this paper is to analyze printed advertising campaigns that took "Kıpkırmızı" award that is the grand prix of Kırmızı Awards since 2010. Qualitative research methods based on the content analysis were used for data collecting and analyzing the content of the visuals and texts. The used photos and the text creators in the visual message have been studied. These advertisements have been analyzed in the context of visual storytelling by the content analysis method.
\end{abstract}

Keywords: Advertisement, Photography, Kırmızı Awards

Arş. Gör. Dr. Pelin Öztürk Göçmen, Gazi Üniversitesi, Güzel Sanatlar Fakültesi,

Görsel İletişim Tasarımı Bölümü, Ankara.

E-posta: pgocmen@gazi.edu.tr 


\section{Giriş}

İletişimin gerçekleşebilmesi için oluşturulan, gerek görsel gerekse yazınsal her metnin, kendinden önceki metinlerin yenidensunumu olduğu söylenebilir. Bu yeniden sunumlar, başka bir deyişle yeni kurgular, yazınsal/ sözel metinler ile sanatsal metinler arasındaki etkileşimli alanda da var olmaktadır. Reklam, tüm bu metin türlerini, gerek sanatsal kaygılarla gerekse iletişimsel amaca yönelik nesnel ifadelerle, gerçeğinden de gerçek görünebilmek için kullanır. Hedef kitlesi içerisinde mümkün olan en fazla kişi sayısına ulaşabilmek için de sıklıkla fotoğraf kullanımına başvurur. Insanlık tarihinebakıldığında görme, konuşmadan önce gelir (Berger, 1990: 7). İletişimde, görsel ögelerher zaman etkili rol oynarlar.

Reklamda sıklıkla kullanılan hikâye anlatma geleneği de, yazılı kaynakların ortaya çıkmasından çok öncelere uzanır. Homeros çağında doğan bu geleneğin doğuda başlangıcı, "destanlarda, Binbir Gece Masalları'nda, Nasrettin Hoca fıkralarında, Dede Korkut ve meddah hikâyelerinde" (Dede, 2005'ten aktaran İnceelli, 2005: 133) görülür.

İlk reklam örnekleri, papirüs veya duvar üzerine yapılan çizimler aracılığı ile hikâyeleri iletme amacı taşımıştır. Mısır'da kaçan esiri bulup getirene ödül verileceğini duyuran papirüs, esirlerin fiyat ve özellikleri kazınmış duvarlar (Ünsal, 1984: 20), ilk reklam örneklerini oluşturur. Hitit, Yunan, Roma uygarlıkları tarafından da çeşitli nedenlerle reklam örnekleri kullanılmıştır.

Betil'e (1975: 14) göre okuma yazma bilmeyenlerin de anlayabilmesi için ortaçağda İngiltere'de satılan ürünün görsel simgesinin bulunduğu tabela kullanmak zorunludur. Böylece amblemin ilk örnekleri ortaya çıkmıştır. Kâğıt ve baskı tekniğinin bulunuşu görsel iletişim tarihi içerisinde önemli bir yere sahiptir. Onyedinci yüzyılda basının, yeni bir iletişim aracı olarak doğduğu ve modern reklamcılığa adım atıldı̆ı görülür (Ünsal, 1984: 22). Litografinin gelişmesi sonucu baskı kalitesi artmıştır. Böylece kaliteli görsellerin kullanıldığı reklamların yaygınlaşması mümkün olmuştur. Fotoğrafın bulunuşu ise görsel iletişimin en önemli tarihsel gelişmelerinden birisidir. Niepce 1826 'da ilk görüntüyü elde ettikten sonra 1839'da Daguerre'nin emülsiyonu kalıc kılma çalışmaları Talbot ve Archer'ın yöntemleri ile gelişmiştir (Sim Süldür, 2003: 402). Bu tarihten sonra fotoğrafın kullanımı hızla yaygınlaşmıştır. 
1880'lerden sonra reklam, ulusal pazarlama örgütlerinin kurulmasına dâhil olan, pazarlama karmasının en önemli elementlerinden biri olmuştur (Schudson, 1989: 59). 1890-1925 yılları arasında yapılan reklamcılıkta, ürünün tanıtılması amaçlanmıştır. Markalaşmanın henüz önemli olmadığı bu dönemde, tüketiciyi ikna etmek için öncelikle dikkatini çekmek gerekmektedir.

Gittikçe artan bir hızla sanayileşmeye başlayan ondokuzuncu ve yirminci yüzyıl toplumlarında dünyaya yeni gelen insanların toplumsallaştııılmaları için aile dışında karakter biçimlendirici organlara gereksinim duyulmasının yanı sıra, yetişkin insanların da toplumsal ilişkilerini düzgün ve etkin bir biçimde işlerli tutabilmek için gereksinebilecekleri dünyaya ve toplumsal yaşamın çeşitli olgularına ilişkin bilgi ve haber alabilmeleri de değişmiştir. Bu kişilerin dünyayı öğrenmeleri kitle iletişimi dediğimiz yeni iletişim biçimi aracılığılyla olmaya başlamıştır (Oskay, 2000:239).

Ondokuzuncu yüzyıl sonlarında üretimin çoğalması, dağıtımın etkisini arttırması ve pazarlama stratejisinin rekabete dayanması, üreticiyi diğerinden farklılaştırmaya yarayan marka avantajlarının fark edilmesini sağlamıştır. Markalaşma başarıldıktan sonra ikinci önkoşul, markalı ürünleri tüketiciye taşımaktır (Fowles, 1996: 37). Bu noktada markalar, pazarlama karmasının tüm bileşenlerinden yararlanarak, kendilerinin tercih edilmesini sağlamak için tüm imkânlarını kullanmışlardır. Bunların başında da reklam ve tanıtım faaliyetleri gelmiştir.

Amerika' da tüketimin önem kazanmaya başladığı yılları takiben 1920'lerde pazarlama, satış ve reklamı da kapsayarak en az üretim kadar önemli bir konuma gelmiştir. Marchand'ın (1985: 31) da ifade ettiği gibi üreticiler sadece mal üretimi yapmaktadır, oysa reklam yazarları daha yüksek üretim düzeyinde iş görmektedirler; onlar tüketici üretmektedirler.

20. yüzyıl başlarında reklamcılığın iki görevi söz konusudur. Bunlardan ilki, kitlesel olarak üretilen malların pazarlanmasına yardımcı olarak tüketilmelerini sağlamaktır. Reklam birinci işlevini, malların nasıl kullanılacağı konusunda rehberlik ederek, mal kullanımının modernliğin bir parçası olduğunun altını çizerek gerçekleştirmiştir. Reklamın ikinci işlevi ise; anonim şehir yaşantısı içinde insanların benlik arayışında, onlara benliklerini sunma, teşhir etmek için mal tüketimini önermektir. Reklam bu işlevini, insanların yaşadığı boşluğu reklam sloganlarıyla doldurmak suretiyle yerine getirmiştir (Yavuz, 2013: 7). 
Bu bağlamda, reklamların en gerçekçi mesajları verebilmek için başvurduğu en etkili araç, slogandan sonra fotoğraf olmuştur. Bu noktada, reklam fotoğrafının, reklamda kullanılan diğer tüm ögelerle aynı dili konuşuyor olmasının önemi açıkça ortadadır.

\section{Fotoğraf - Reklam Ilişkisi}

Frizot'a (1998: 556) göre yirminci yüzyılın en fark edilir sosyal olaylarından biri, basit reklamın tanıtım endüstrisine dönüşmesidir. İkisi arasındaki temel fark, kullandığı araçlardadır.

Fotoğrafın reklam amaçlı kullanımının ilk örnekleri 1850'lerde görülmeye başlanmıştır. Ancak dönemin teknolojik kısıtlamaları nedeniyle yaygınlaşamamıştır. ilk fotoğraflı afişler, 1900'lerin başlarından itibaren tasarlanmaya başlanmıştır. Yirminci yüzyılın ilk yarısında, fotoğrafı, grafik tasarım ürünlerinde kullanan tasarımcılar içinden ilk akla gelenler arasında, Aleksandr Rodchenko, Charles Coiner, El Lissitzky, Gustav Klutsis, Henry Wolf, Jan Tschichold, John Heartfield, Karel Teige, Ladislav Sutnar, László Moholy-Nagy, Lewis Hine, Max Burchartz, Michael Dolgorukow, Mieczysław Szczuka, Paul Sehuitema, Piet Zwart, Teresa Zarnowerve, Wojciech Zamecznik sayılabilir. August Sander, Edward Steichen, Paul Outerbridge ve Richard Avedonise yirminci yüzyıl reklam fotoğrafçılığının öncüleri arasında yer almışlardır. 1920'lerde reklamların yaklaşık yüzde on beşinde fotoğraf kullanılırken, 1930'larda bu oran yüzde seksenlere çıkmıştır (Johnston, 1997: 1). 


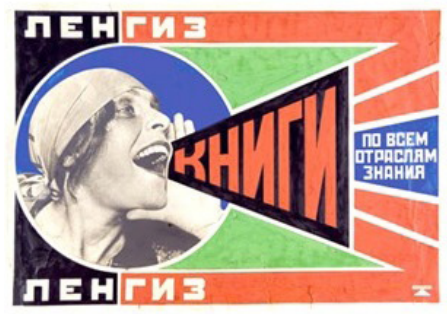

Aleksandr Rodchenko, 1924, Afiş

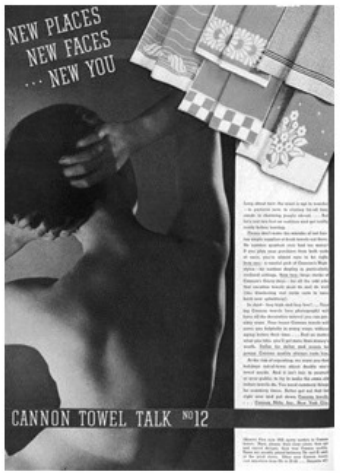

Charles Coiner, 1936, Afiş

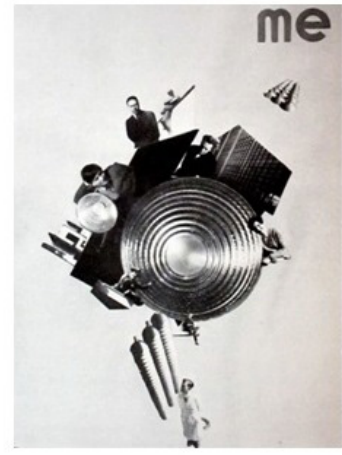

László Moholy-Nagy, 1925, Fotomontaj|

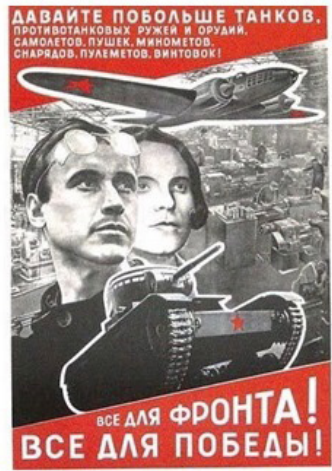

E. E1 Lissitzky, 1941, Afiş

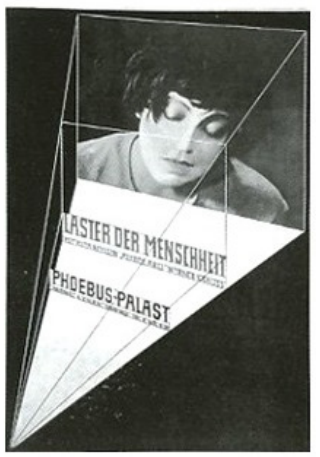

Jan Tschichold, 1928, Afiş

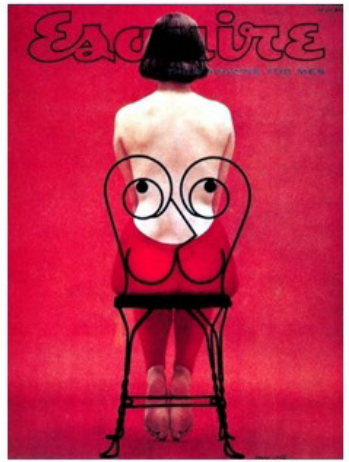

F. Henry Wolf, 1952, Dergi Kapağ1

Görsel I. Fotoğraf Kullanılan Grafik Tasarım Örnekleri

Fotoğrafın, grafik tasarım diline dâhil edildiği ilk örneklerde, çok sayıda katmandan oluşan montaj ve fotomontaj tekniklerini de kullanarak karmaşık mesajları iletme konusunda yeni bir dil oluşturma çabası Görsel 1 'de de görülmektedir. Bu dönemde fotoğraf, tipografinin yanısıra, onu destekleyici bir öge olarak karşımıza çıkmaktadır. Bazı tasarımcıların, endüstriyel gelişimin takdirine katkıda bulunmak için fotoğraftan yararlanmış olduğu da söylenebilir. İdeolojik afiş tasarımlarının ön planda olduğu bu dönemde, reklam amaçlı tasarımlar da görülmektedir. Dönemin tasarımcıları tarafından fotoğrafın, "zengin ideolojik konuları" içinde barındıran bir sanat alanı olarak nitelendirilmiş olması, reklamın da sanat olup olmadığı tartışmasının ileride doğmasına zemin hazırlamıştır. Yılmaz'ın (2006: 374) da vurguladığı gibi Rutherford, iletişimcilerin babası kabul edilen McLuhan'ın izinden giderek, reklamcılığın zamanın sanatı olduğunu savunmuştur. Günümüzde bu tartışma yön değiştirmekle 
beraber; reklam kampanyalarının ölçümleri sonucunda, sanatsal bir reklamın satışları etkileyip etkilemediği tartışımaktadır.

1920'lerden sonra reklamcılar, ürünü merkeze almaktan vazgeçmişlerdir. O dönemde, insan doğasının duygusal güdülere yaslandığı düşünülmüştür. Böylece reklamlar ürün değil, ürüne dair sembollerin yer aldığı iletişim formlarına dönüşmüştür.

1931 yılında Domela tarafından düzenlenen uluslararası fotomontaj sergisinde, eşsiz tipografilerle fotoğrafların bir araya getirildiği reklam fotomontajları sergilenmiştir (Weill, 2007: 54). 1935'te renkli filmin bulunuşuyla birlikte çekilen fotoğraflar, reklamların etkileyici ve daha inandırıcı olmasına neden olmuştur. Ancak 1950'lerde renkli fotoğraf baskısı yaygınlaşana kadar, tasarlanan grafik ürünlerde çoğunlukla siyahbeyaz fotoğraflar kullanılmıştır.

Reklamcılıkta yaratıııık devriminin yaşandığı dönem olarak adlandırılan 1950 sonrasında, yeni bir reklam dili oluşturulmaya başlanmıştır. Bu dönemde televizyon, yepyeni ve kuvvetli bir reklam mecrası olarak yayın hayatına girmiştir. Amerika'da Leo Burnett, David Ogilvy gibi reklam ajansları ve CBS televizyon stüdyoları da bu dönemde kurulmuştur. Televizyonun üstünlüğü karşısında pek çok basın-yayın organı kapanmıştır. Varlığını sürdürmeyi başaran büyük tirajlı basın-yayın organlarında yer alan reklamlar ise önemini korumuştur.

1985 yılından itibaren yükselişe geçen dijital teknoloji, fotoğrafın üretim ve sunum biçimlerinin değişmesine neden olmuştur. Bu gelişmeler sonucunda imajları manipule etmek için çeşitli yazılımlar geliştirilmiştir. Fotoğrafı çekilen ürünün zeminden kolayca ayrılabilmesine olanak veren çeşitli ürünler üretilmiştir. Böylece tüm bu dijital imajların birbirleri ve/ veya diğer tasarım ögeleri ile birlikte, pek çok farklı kombinasyonda kullanılmaları mümkün olmuştur. Günümüzde reklam, tamamen dijital imajlarla ve dijital yöntemlerle üretilir, değiştirilir, manipule edilir, kullanılır, saklanır durumdadır.

$\mathrm{Bu}$ değişimler ile birlikte, hikâyelerin bir insandan diğerine aktarım şekli ve amacı farklılaşmıştır. Modern toplumda, kitle iletişim araçları "anlatıı" dır. "Dinleyen" modern insan ise, bilgilerini yaşam 
deneyimlerinden kazanma yerine, haberdar edilme durumuna geçirilmiştir. Anlatıcı ve dinleyenler birbirlerinden ayrılmışlardır. Öte yandan günümüzde interaktif mecraların artışına ve kullanım sıklığına paralel olarak anlatıcı ve dinleyici rolleri de birbiri ile iç içe geçmiş durumdadır. Ancak her iki durumda da, Kocabaş v.d.'nin de (2000: 17) belirttiği gibi simgeler bütünü olan iletinin iyi düzenlenmiş olması, iletişimin başarısında büyük önem taşımaktadır.

Fotoğrafın bulunuşu ve her geçen gün gelişmekte olan teknoloji ile birlikteliği, görsel iletişime yeni boyutlar kazandırmaktadır. Fotoğrafın, gerçekliğin yeniden sunumundaki en belirgin sınırlılığı olan iki boyutluluğu, fotoğrafa konu olanın yalnızca başka bir fotografik görüntü mü veya gerçekliğin kendisi mi olduğu sorusunu her zaman cevapsız bırakır (Derman, 1989: 193). Bu sorunun cevabı her zaman net olmasa da, görsel belleğimize sürekli aslının yeniden üretimi olan görüntüler eklenmesine yardımcı olur. Kişi, içinde yaşadığı dünyayı, genellikle, mümkün olan tek dünya gibi algılar. Yaşam, çoğu kişinin kendisince oluşturulan göstergelerle anlamlanır. Bu göstergelerin yeniden sunumsal niteliği, bir gerçeklik izlenimini yaratır. Bir şey, başka bir şeye benzediği oranda, onun yeniden sunumudur. Bu benzerliği en etkili şekilde kullanan, bir ürünü basılı mecralarda en iyi şekilde yeniden sunangörsel iletişim aracı fotoğraftır. Ogilvy'nin (1989:145) de değindiği gibi fotoğraf, gerçeğin sunumudur.

Üretim-tüketim ilişkisi içerisinde görsel iletişimin önemi, günümüzde dahi, giderek artmaktadır. Ulus aşırı üretim ve tüketim ilişkileri, yerel olan metin kullanımı yerine evrensel olan görsel kullanımını gerekli kılmıştır. Öncesinde metni desteklemek için kullanılan fotoğraflar artık ön planda, büyük boyutta yer almakta ve metin, fotoğrafa destek olmaktadır. Bu noktada da ürünü en iyi şekilde anlattığı kabul edilen fotoğrafın, iletişimin uluslararası alanda gerçekleşebilmesinde üstlendiği rolün önemi ortadadır.

\section{Yöntem}

Bu çalışmada, on yıldan bu yana basıı reklamlara verilen Kırmızı- Basında En İyiler Reklam Ödülleri içerisinden 2010 yılından bu yana, büyük ödül olan "Kıpkırmızı" ödülünü almış olan beş reklam incelenmiştir. Verilerin toplanması, analizi, metin ve görsel içeriğin incelenmesinde içerik analizine dayalı nitel araştırma yöntemi kullanılmıştır. Reklam fotoğrafları 
slogandan ve tasarımdan ayrı düşünülemezler. Bu nedenle, en iyi basın reklamı ödülünü almaya hak kazanmış reklamlar üzerinden reklam ile fotoğraf ilişkisi bütünsel bir yaklaşımla, görsel hikâye anlatımı bağlamında irdelenmiştir.

\section{Bulgular}

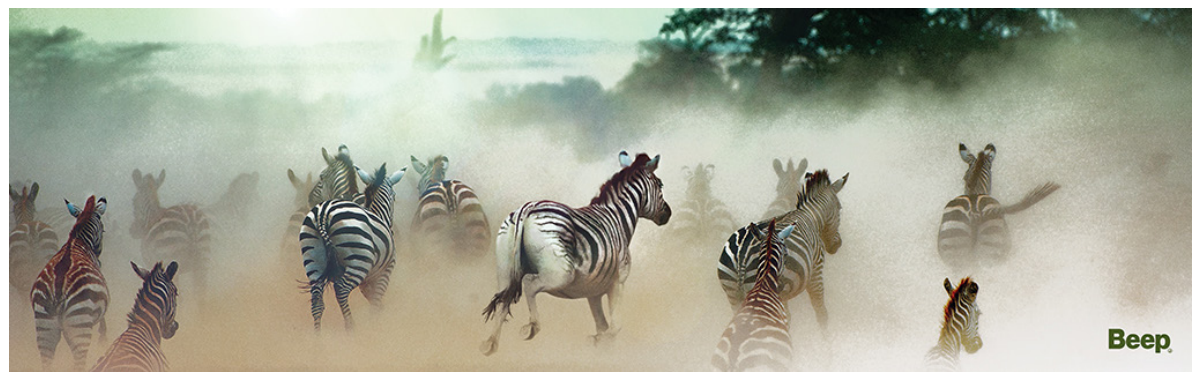

Görsel 2. Leo Burnett Istanbul, Jeep Türkiye, 2014, Basın Reklamı, $65 \times 30 \mathrm{~cm}$. 2014 Kıpkırmızı Ödülü

SUV'nin yaratıcısı Jeep, logo kullanmadığı Görsel 2'deki bu reklam çalışması ile doğa ve araziyi ne kadar sahiplendiğini vurgulamaktadır. Logonun kullanılmaması nedeniyle "cesur" olduğu söylenebilecek olan bu reklamda Helvetica Bold yazı karakteri ile yazıımış Jeep'i andıran kelimeler, marka hakkında ipucu vermektedir. Kırmızı Ödülleri web sayfasında, ödülü alan reklam olarak bu tasarım gösterilmektedir. Ancak aynı kampanya kapsamında "Deep ve Keep" kelimelerinin kullanıldığı iki tasarım daha yer almaktadır. Vahşi doğanın içinde, koşan zebraların hemen arkasından gitmesini konu edinen bir hikâye üzerine kurulan bu reklam, gerçek arazi deneyimini sunmayı vaad etmektedir. Toz duman içindeki fotoğrafa bakıldığında, zebralar kaçıyormuş gibi bir izlenim oluşmaktadır. Zebraları kovalayan hayvan düşünüldüğünde akla aslan gelmektedir. Bu görsel hikâye ile markanın, kendisini, ormanın kralı aslan ile özdeşleştirmiş olduğu söylenebilir. Güç, hız, kontrol gibi özellikler bu şekilde pekiştirilmiştir. Kullanılan görselin fotografik gücü, reklamın etkisini arttırmaktadır. 

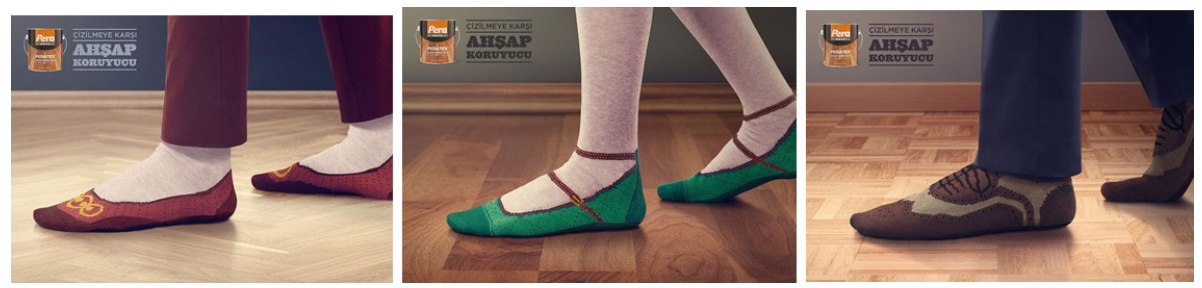

Görsel 3. TBWA/Istanbul, Pera Boya - Ahşap Koruyucu, 2013, Basın Reklamı, 29x2I cm 2013 Kıpkırmızı Ödülü

"Ayakkabı görünümlü çoraplar", bebeklerin ayakkabılarını kısa sürede çıkarmasından rahatsız olan ebeveynler için, bebek çoraplarını ayakkabı görüntüsünde üretme fikrinden yola çıkan bir Amerikan çorap firması tarafından yirmi yılı aşkın süredir üretilmektedir. Bu ürünlerde ana fikir, bebekler için ayakkabı şıklığını, çorap rahatlığıyla birleştirmektir. Görsel 3'te görülen bu reklam kampanyasında bu çorapları giymiş ayak fotoğrafları, farklı desen ve renkte parkeler üzerinde görüntülenmiştir. Tüm reklamlarda rahatlık ve şıklık, kullanılan görsel ile vurgulanmaktadır. Fotoğrafın açısı nedeniyle parke yüzeyinin pürüzsüzlüğü ve temizliği net bir şekilde görülmektedir. Reklamda, sol üst köşede dört kelimelik "Çizilmeye karşı ahşap koruyucu" başlığı kullanılmıştır. Metinde "ahşap" kelimesinin dikkat çekmesi sağlanmış, böylece reklamın çorap ile değil zemin ile ilgili olduğu vurgulanmıştır. Bu metinden önce ise ürün görseli yer almaktadır. Bu reklamda hikâyenin ana fikri, en şık ayakkabılarla, bu ürünün uygulandığı yüzey üzerinde, yüzeyi çizme kaygısı olmadan, sanki çorapla geziyormuş gibi rahatça hareket edebilme özgürlüğü üzerine kurulmuştur. Bu hikâye, farklı ahşap yüzeyler üzerinde hareket ettiği anlaşılan kişilerin ayakkabı görüntüsünde çoraplar giymiş olduğu fotoğrafları ile anlatılmakta, metin ile de desteklenmektedir.
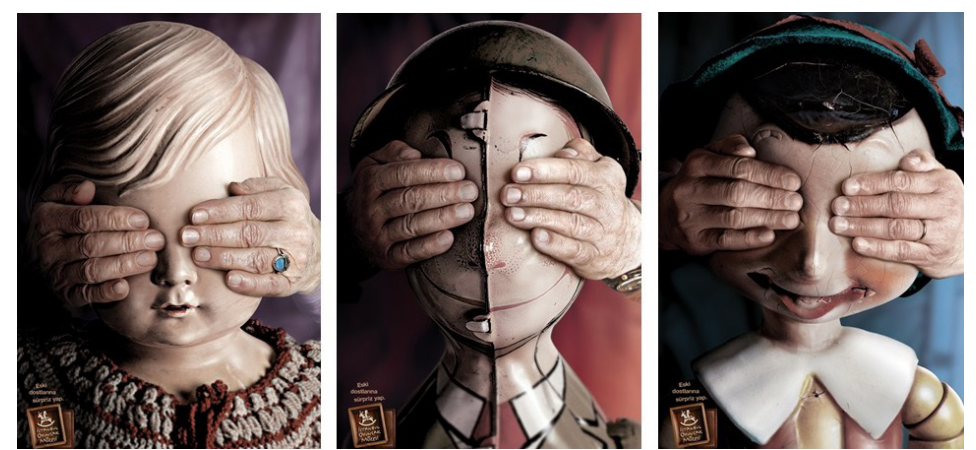

Görsel 4. Leo Burnett İstanbul, Isstanbul Oyuncak Müzesi, 20I2, Basın Reklamı, $21 \times 29 \mathrm{~cm} 2012$ Kıpkırmızı Ödülü 
İstanbul Oyuncak Müzesi'nin, Görsel 4'te görülen bu reklam kampanyasında, özellikle nostaljiden hoşlanan, bir yanı hep çocuk kalan, Peter Pan ruhlu yetişkinleri hedef aldığı söylenebilir. En sevdiklerimizin gözlerini kapatarak, çocukça bir edayla sürpriz yaptığımız çocukluk anılarımızdaki hikâyeleri bize anımsatan bu reklamda kullanılan eski fakat iyi görünümlü oyuncak bebeklerin gözleri, yaşlı olduğu anlaşılan kişiler tarafından kapatılmıştır. "Eski dostlarına sürpriz yap." metni ve İstanbul Oyuncak Müzesi logosu sol alt köşede kullanılmıştır. Metin okuma yönünün tersinde konumlanan bu yazı ile kullanılan fotoğrafın tekrar incelenmesi sağlanmıştır. Oyuncakların en yakınlarımız olduğu günlere atıfta bulunan bu tasarım, içerdiği hikâye ve güçlü fotoğrafik dil ile kişinin reklamla kişisel bir ilişki kurmasına neden olmaktadır.
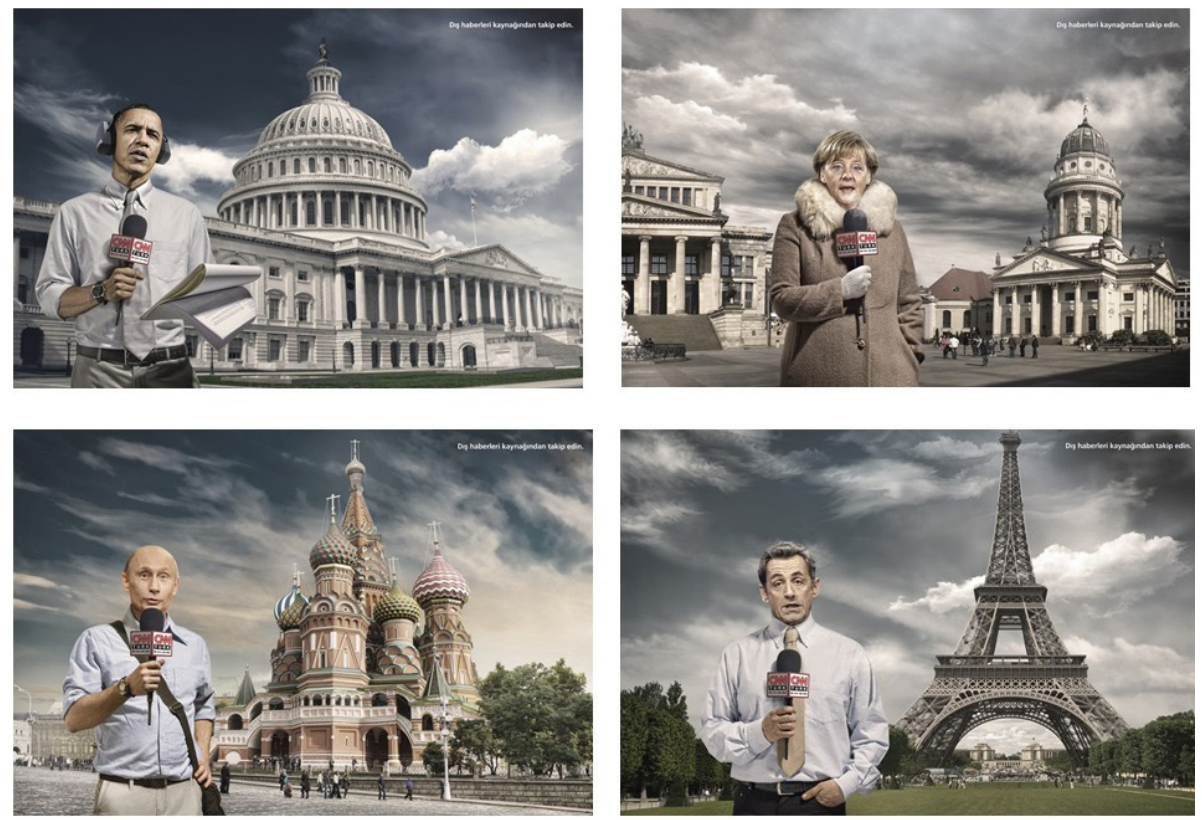

Görsel 5. DDB\&Co Istanbul, CNN TÜRK Dünyadan Haberler, 20I I, Basın Reklamı, $29 \times 2$ I cm. 201 I Kıpkırmızı Ödülü

2009 yılında Lübnan'da Impact BBDO, Beirut tarafından Sarkozy, Hillary Clinton ve Ahmadinejat kullanılarak Tarwij için hazırlanan reklam kampanyası (http://adsoftheworld.com/media/print/tarwij_ sarkozy 20.06.2015) ile gösterdiği benzerlik şaşırtıcı olsa da Obama, Merkel, Putin, Sarkozy gibi dünya liderlerini kendi başkentlerinde CNN Türk için muhabirlik yaparken gösterme fikri, dikkat çekici bir reklam 
kampanyasına dönüşmüş denebilir. Görsel 5 'te görülen bu kampanyada dünya liderlerinin fotoğrafları, çeşitli görüntü işleme teknikleri ile kendi ülkelerinin ünlü yapıları önünde muhabirlik yapıyormuş gibi gösterilmiştir. Kullanılan görseller, "Live from the source / foreign politics mon-fri at $2 \mathrm{pm}$ " metni ile birlikte okunduğunda oldukça rasyonel, sade ve dolaysız bir mesaj içerdiği açıktır. Öte yandan bu reklamların, haber niteliği taşıyan bilgilerin bu liderlerin elinde/tekelinde olduğunu çağrıştırabileceği ve CNN Türk'ün bu politikacıların propagandasını yapan bir kanal olarak algılanmasına neden olabileceği unutulmamalıdır.

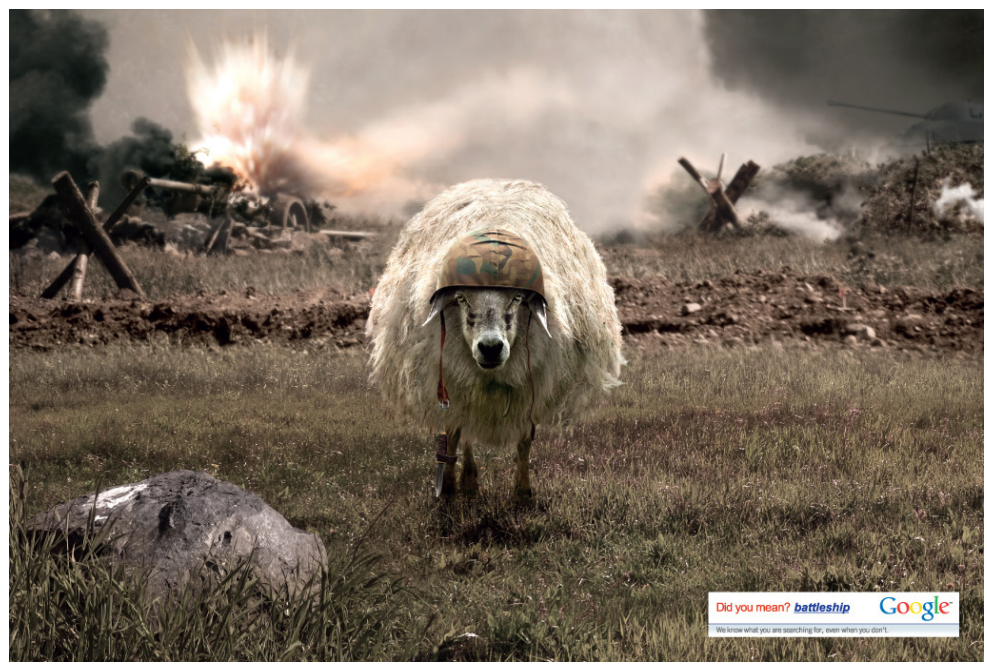

Görsel 6. Grey Istanbul, Google Türkiye, 2010, Basın Reklamı, 29×21 cm. 2010 Kıpkırmızı Ödülü

Google'ın "Did you mean? (Bunu mu demek istediniz?)" özelliğini vurgulayan Görsel 6'daki bu reklam, "battleship" ile "battlesheep" kelimelerini kullanarak espirili bir tasarıma imza atmıştır. "Savaş gemisi" yerine "savaş koyunu" olduğu anlaşılan bir görsel ve sol alt köşede "Did you mean? battleship" düzeltmesi, Google logosu ile, ekranda görmeye alışık olduğumuz şablonda kullanılmıştır. Bu reklamda, sosyal medyada da hızla yayılabilecek, komik bir fikir uygulamaya geçirilmiştir. Koyunun savaşın içinde olmasına rağmen bu kadar "beyaz" kalabilmiş olmasının nedeninin kontrast yaratma kaygısı olduğu düşünülebilir. Fotoğrafta görülen ön bacaktaki bıçak, kafadaki kask ve buna eklenen arka plandaki savaş görüntüsü ile düz anlamı ön plana çıkartmış bir reklam tasarımı yapılmıştır. Fotografik imge olarak burada kullanılan koyun, temsil ettiği 
gerçekliğinden daha fazla ilgi çeker hale getirilmiştir.

\section{Sonuç}

Hikâye anlatımı en iyi iletişim kurma yöntemlerinden birisidir. Hedef kitlenin kendi deneyimlerine atıfta bulunması, bu durumun temel nedenidir. Hikâyeler, markaların güvenilirliğini arttırmakla beraber markanın kişileştirilmesine de yardımcı olabilmektedir. Anlatılan hikâyenin hedef kitle deneyimi ile örtüşmesi halinde, markanın, diğer içerikler arasından göze çarpmasını ve dikkat çekmesini sağlar. Hedef kitle, hikâyenin sonuca ulaşıp ulaşmadığından bağımsız olarak, marka ile daha çok ilgilenir ve ürünle kendini ilişkilendirir. Hikâyenin devamını bilememek, merak duygusunu kamçılar. Bilimsel olarak da kişisel deneyimlere dokunduğu için hikâyelerin etkili olduğu kanıtlanmıştır.

Messaris (1997: 213), reklamlardaki görsel imgelerin başlıca üç temel rol oynadığını; bunlardan birinin bir şeylerin gerçekten olduğuna ilişkin fotografik deliller sunmak olduğunu ve reklamlardaki bu imgelerin, görsel iletişimin temel karakteristik öğelerini oluşturduğunu belirtmektedir. Cappo'nun (2003: 10) da dediği gibi reklamclık, problem çözümüdür, film çevirmek değildir. Problemi çözmek de her zaman tek başına yeterli olmaz, reklama şüphe ile yaklaşan hedef kitleyi ikna etmeyi başarmak durumundadır.

Reklamda nihai amaç olan "ürün satışının" gerçekleşmesi için, kültüre ilişkin tüm değerlere başvurulur. Pektaş (1993: 2), düşüncelere etki edilecek, gerçekler gösterilecekse görüntü ögesi olarak gerçek fotoğraf veya resim kullanılmasının gerekliliğinden söz eder. Reklamlarda fotoğrafla sunulan görüntü, gerçeğinden çok daha kusursuzdur. Ayrıca fotoğrafın doğası gereği gerçek ile kurduğu tanıklık ilişkisi, reklamda verilmek istenen mesajın, olduğundan daha da gerçek ve ilgi çekici bir bağlamda sunulmasına olanak sağlamaktadır.

Bu çalışma kapsamında incelenen beş basın ilanında da görsel imgeler, fotografik bir dille sunulmuştur. Tümünde anlatılmak istenen hikâye, fotografik imgeler ile kurgulanmış, çok kısa metinler ile desteklenmiştir. Kullanılan imgelerin tümü, tüketiciyi anında etkileyebilecek gücü yaratmak için kurgulanmıştır. 
2014 yılı Kıpkırmızı ödülünü alan Jeep reklamı, kendisini lider olarak konumlandırdığı bir hikâye üzerine kuruludur. 2013 yılında ödül alan Pera Boya/Ahşap Koruyucu, rahatlık ve şıklık temalarının vurgulandığı bir hikâyeyi seçmiştir. 2012 yılında ödül alan İstanbul Oyuncak Müzesi, çocukluk anılarını canlandırma kaygısı taşıyan bir hikâye üzerine tasarlanmıştır. 2011 yılında ödül alan CNN Türk Dünyadan Haberler, dünya liderleri ile rasyonelliği vurgulamaya çalışan bir tasarıma imza atmıştır. 2010 yılında ödül alan Google Türkiye reklamı ise esprili bir hikâye kurgulayarak, ürünün özelliklerinden birisini ön plana çıkartmaya çalışmıştır.

Tüm reklamlarda kullanılan görseller etkili, dikkat çekici ve merak uyandırıcıdır. Öte yandan, kullanılan fotoğrafların hiçbirisi, ürünün kendisine ait değildir. Günümüzde inandırıcılığın yolunun, fotografik görüntüler üzerinden gittiği gerçeği unutulmamakla birlikte, kullanılan görüntülerde kullanııının deneyiminin vurgulandığı görülmüştür. Böylelikle bu reklamlar görüldüğünde oluşan duygu ve düşüncelerin, ürün kullanıldığında gerçeğe dönüşeceği vaad edilir. Söz konusu reklamlarda kullanılan fotoğraflar ile Jeep, maceracı; Pera Boya, rahat ve şı; İstanbul Oyuncak Müzesi, nostaljik; CNN Türk, gündemi takip eden ve Google Türkiye, internet aramalarının doğru yapıldığı birer deneyim sunmuştur. 


\section{Kaynakça}

Berger, J. (1990). Görme Biçimleri. İstanbul: Metis Yayınları.

Betil, T. (1975). Grafik-Yazı-Endüstri Grafisi. İstanbul: Devlet Güzel Sanatlar Akademisi Uygulamalı Endüstri Sanatları Yüksek Okulu Ders Notları.

Cappo, J. (2003). Reklamcılığın Geleceği. ìstanbul: Mediacat Yayınları.

Derman, I. (1989). Fotoğraf ve Gerçeklik. Eskişehir: Anadolu Üniversitesi Yayınları.

Fowles, J. (1996). Advertising and Popular Culture. London: Sage Publishing.

Johnston, P. (1997). Real Fantasies Edward Steichen's Advertising Photography. California: University of California Press.

Kocabaş, F., Elden, M., Yurdakul, N. (2000). Reklam ve Halkla ilişkilerde Hedef Kitle. istanbul: iletişim Yayınları.

Marchand, R. (1985). Advertising in American Dream: Making Way for Modernity 19201940.Berkeley: University of California Press.

Messaris, P. (1997). Visual Persuasion: The Role of Images In Advertising. London: Sage Publications.

Ogilvy, D. (1989). Bir Reklamcının itirafları. ístanbul: Afa Yayınları.

Oskay, U. (2000). Tek Kişilik Haçlı Seferleri. i̇stanbul: İnkılap Yayınları.

Schudson, M. (1989). "Historical Roots of Consumer Culture”, R. Howland ve G.B. Wilcox Lincolnwood. (Editörler).Advertising in Society: Classic and Contemporary Readings on Advertising Role in Society, Illinois: NTC Business Books. s. 42-72.

Sim Süldür, N. (2003). "Üretim-Tüketim Ilişisisi Içinde Gelişen Görsel Iletişim ve Etkin Kullanım Alanı: Tanıııma Yönelik Fotoğraf", İstanbul Üniversitesi Iletişim Fakültesi Dergisi. 18, 395-4l6.

Ünsal, Y. (1984). Bilimsel Reklam ve Pazarlamadaki Yeri. İstanbul: ABC Kitabevi.

Weill, A. (2007). Grafik Tasarım. İstanbul: YKY 
Yavuz, Ş. (2013). “Türk Toplumunun Tüketim Toplumuna Dönüşümünde Reklamcıllğın Rolü”, Gazi Üniversitesi İletişim Fakültesi Illetişim Kuram ve Araştırma Dergisi. 36 / Bahar, 219-240.

Yılmaz, M. (2006). Modernizmden Postmodernizme Sanat. Ankara: Ütopya Yayınevi.

\section{İnternet Kaynakları}

Inceelli, A. (2005). Dijital Hikâye Anlatımının Bileşenleri. The Turkish Online Journal of Educational Technology - TOJET.Temmuz 4, 3.I32-I42. Erişim: 5.II.20I5. http://www. tojet.net/articles/v4i3/43/8.pdf.

Pektaş, H. (1993). Basın Illanlarında Grafik Tasarım ve Layout. H. Ü. Güzel Sanatlar Fakültesi Sanat Yazıları 5. Ankara. s. 91 .Erişim: 03.12.2013. http://www.hasippektas. com/bas.ila.html

\section{Görsel Kaynakları}

Görsel I. Erişim: 25.03.20I6 http://metropolis.co.jp/arts/art-reviews/rodchenkostepan ova-visions-of-constructivism/; http://mondo-blogo.blogspot.com.tr/20I I/I I/ get-into-laszlo-moholy-nagy.html;http://designblog.rietveldacademie.nl//wp-content/ uploads/2009/05/jan-tschichold-and-his-pictorial-posters.pdf Erişim: 27.03.2016 http://www.printmag.com/j-j-sedelmaier/charles-t-coiner/ Erişim: 29.03.2016 http://www. dieselpunks.org/profiles/blogs/soviet-wwii-posters; http:// www.historygraphicdesign.com/the-age-of-information/the-new-york-school/680-henrywolf

Görsel 2. Erişim:I I.09.20I5 http://www.kirmiziodulleri.com/Kazananlar.aspx

Görsel 3. Erişim:I I.09.20I5 http://www.kirmiziodulleri.com/Kazananlar.aspx

Görsel 4. Erişim: I I.09.20I5 http://www.kirmiziodulleri.com/Kazananlar.aspx

Görsel 5. Erişim:I I.09.20I5 http://www.kirmiziodulleri.com/Kazananlar.aspx

Görsel 6. Erişim: I I.09.20I5 http://www.kirmiziodulleri.com/Kazananlar.aspx 